\title{
Analysis on Transfer Pricing of Multi-national Corporation
}

\author{
Xiaoming Qiao \\ Journal Editorial Department, Yunnan Normal University, Kunming, Yunnan, 650092
}

Keywords: Multi-national Corporation, Transfer pricing, International tax avoidance

\begin{abstract}
With the continuously introducing foreign capital in China, the transfer pricing issues are paid much more attention. Originated in international tax allocation, transfer pricing issuesit is an important means to achieve global strategy and international tax evasion. This paper, based on the concepts of transfer pricing and its motivation, takes GlaxoSmithKline's case as an example to analyze more specifically, sums up the negative impact of transfer pricing on China's economy, and proposes policy suggestion.
\end{abstract}

\section{Introduction}

Since the large-scale investment attraction in China in the 1980s, a large number of major countries in the world have been flooded with funds. Many well-known international companies have invested and set up plants in China, which has played a good role in promoting economic development and employment. However, with the ever-expanding number of multinational corporations, the most obvious problem in its internal transactions, the transfer pricing, has also gradually spread in China. Transfer pricing involves the taxation of affiliated enterprises in international taxation. Improper internal transactions and pricing not only affect the distribution of tax revenue, but also adversely affect the macroeconomic environment of a country. Responding to transfer pricing is a key task of the tax authorities in China and is also a hot spot in the field of international taxation in academia.

Zhang Ji (2007) classifies the motives of multinational corporations' transfer pricing into tax motivation and non-tax motivation. Among them, the motivation for taxation includes avoiding income tax, import tax and withholding tax; non-tax motivation includes profit adjustment, capital allocation, avoiding host country price control, Avoid foreign exchange risk avoidance of foreign exchange control, offsetting inflation and utilizing host country preferential policies [1]. Zhang Qiaoqiao (2007) summarizes the negative impact of transfer pricing on China, including tax losses, undermining fair competition, disrupting normal economic order, reducing the effect of foreign direct investment, reducing the balance of payments in China, and causing Chinese employees Wages and benefits are difficult to improve and improve [2]. Zhang Ji (2012) analyzed the game model of transfer pricing avoidance of multinational corporations (MNCs), and concluded that the tax avoidance costs of MNCs' transfer pricing are inversely proportional to the probabilities of tax avoidance investigations conducted by the tax authorities in host countries. Transfer pricing is directly proportional to the cost of the survey, and the host country is inversely proportional to the income tax rate, which is inversely proportional to the host country's penalty rate for transfer pricing and tax avoidance [3]. Li Yan (2013) argues that the combination of formula allocation and transfer pricing can ease the group's conflict between tax benefits and management benefits. Because the formulating method is more simple and convenient in terms of realizing the tax fairness than the transfer pricing meeting the principle of independent transaction, it needs improvement in formula accuracy [4]. Luo Yu (2014) analyzes the relationship between trade protection and transfer pricing. When transfer pricing is intensified between multinationals, countries implement trade protection policies to protect their own interests, leading to the old trade protection driving the transfer pricing. However, the transfer pricing further aggravates trade protection [5].

Transfer pricing is not only China, but also a problem that various countries pay attention to in order to solve the need of international tax distribution. Only through continuous exploration and reform can we gradually strengthen trade cooperation among all countries, resolve trade disputes 
and optimize the international economic environment. Although the research on transfer pricing has been very extensive, there are few case studies of real enterprises. The following will take GSK as an example to conduct a case study on the transfer pricing of multinational corporations.

\section{GSK transfer pricing case}

GlaxoSmithKline (GSK) is the only multinational company that develops drugs and vaccines for the three major global diseases (malaria, AIDS and tuberculosis) identified by the World Health Organization. 2001 GlaxoSmithKline (China) Investment Co., Ltd. was established (hereinafter referred to GSKCI Company). After the establishment of GSKCI in China, GSKCI injected advanced pharmaceuticals and pharmaceutical technologies into our country and quickly opened up the Chinese market. The performance of GSKCI also continued to grow, but the problems followed. September 19, 2014 GSKCI's commercial bribe ended with a fine of 3 billion yuan. With the exposure of bribery cases, the issue of transfer pricing of multinational corporations has also gradually been taken seriously. The way GSK operates is that the prices of finished medicines exported to China are much higher than those of other countries and the high profits are left abroad. At the time of exporting finished medicines to China, the retail price of high profit was taken as the cost price of GSKCI Company in China, on the basis of which GSKCI Company implemented a pricing strategy to ensure profit. In addition, GSK also benefited from the reprocessing of imported raw materials. For example, the raw materials of the drug Xilixin were processed by a GSK company in a branch in Cyprus. After a price transfer, the bottle was bottled in Italy and the Italian branch office A price transfer, arrived in China labeled [6]. GSK can not only realize the interests of the Cyprus and Italy branches, but also reserve part of the profits abroad and reduce its own tax on the surface of seemingly small profits or even losses, through continuous transfer pricing. Negative, in order to maximize the profits of the head office and foreign branches.

In addition to indirect increase in drug prices for profit, marketing of intangible assets is also a common means of transfer pricing. The tax dispute between the Internal Revenue Service (IRS) and GSK on transfer pricing was for 16 years and the IRS considered that GSK had improperly transferred its profits to the United Kingdom. Its tax disputes mainly focus on the transfer pricing of intangible assets. The scope of intangible assets mainly includes patents, trademarks, research and development, labor services, marketing strategies, etc. Due to its own exclusivity and proprietaryness, it is difficult to find comparable targets and reference standards and it is difficult to mix with other property transactions. Split, and thus its transfer pricing issues more complicated. Headquartered in the United Kingdom, GSK is headquartered in the United Kingdom with a research and development function and parent company's trademark and patent rights in traditional medical products, research and development technology, marketing strategies, etc. GSK UK's parent company owns all of the company's intangible assets. GSK U.S. affiliates are chargeable for charge and marketing activities with the permission of the parent company and, where permitted, U.S. affiliates enjoy the benefits of the parent intangible assets and pay royalties to the British parent. GSK believes that its parent company provides "tradable intangible assets" to its subsidiaries, that is, the parent company has generated huge profits from its proprietary technology through its high-risk and high-cost research and development activities, so that the parent company should enjoy Most of the profits However, the IRS authorities think that GSK's U.S. subsidiary enjoys more "marketing intangible assets" and gains huge profits through a series of activities such as trademark use, advertising, promotion and promotion. Therefore, most of the profits should be attributed to subsidiaries and parent companies can get a reasonable royalties, do not enjoy excess profits. Eventually, the transfer pricing case ended in a settlement between the two parties, GSK paid the taxes, and the IRS lifted the tax evasion charges against GSK [7]. However, this protracted case led to the high cost of time and administrative costs, indicating the economic and social harms caused by transfer pricing. This prompted us to conduct an in-depth study on this issue and find out what to do about it. 


\section{The international transfer pricing analysis}

Through the operation of the above GSK transfer pricing in China and the United States, it can be seen that the international transfer pricing is a transnational corporation group that is divided into two or more countries but belongs to the same corporation or the same group of companies. Among the affiliates Internal price when trading. Transnational corporations use the differences in tax rates and tax exemption conditions in different countries to transfer their profits to affiliated enterprises in areas with low tax rates or even tax-exempt areas so as to reduce the overall tax burden as shown in the figure below [8]. The various transfer pricing methods adopted by GSK and other multinational corporations are one of the most common and effective international tax avoidance methods at present.

Different from the market price formed under full competition, the price of international transfer pricing is dominated by the interests of multinational corporations. Its determination not only needs to consider the factors to be considered in formulating the general price, but also needs to consider the government relations, legal system, market conditions and level of competition in two or more countries. Due to the complex background of international relations, the price of international transfer pricing has great flexibility.

The ultimate goal of international transfer pricing is to maximize the overall after-tax benefits, but the relatively different pricing standards from market prices often violate the law of market value and may artificially distort the distribution of income and costs among relevant countries, resulting in a The country's tax revenue suffered serious damage, and even harmful to the distribution of tax revenue between countries.

Tax incentives for multinationals to transfer pricing vary widely, either to circumvent certain types of taxes, to avoid multiple taxes, or to maximize the overall benefits. In general, there are five main categories.

Countries generally support foreign investors to invest aggressively to create new productive capacities. They discourage passive investment by foreign enterprises and therefore levy a withholding tax on negative investment income such as dividends, interest, rentals and royalties. In the absence of a tax treaty, the general withholding tax rate is usually high. Such as the United States 30\%, Switzerland 35\%, Japan, the Netherlands, Finland and other countries 25\% [9]. As a result, firms in countries with high accruals often sell products to foreign parent companies at low prices, raising the profits of the parent company, thereby replacing the interest, dividends, rent or royalties that should be paid to the parent company to avoid withholding tax.

In order to reduce the tariffs, some multinational corporations adopt the method of lowering the purchase price when importing goods from foreign affiliates so as to reduce the import dutiable value of the tax at the customs; or through Subcontracting, dismantling and other ways, the purpose is to pay less tariffs [10].

In order to avoid double taxation in the world, foreign countries usually have foreign tax credits in all countries. If a foreign parent's tax base is implemented in the country where the parent company of the affiliated enterprise is operating and the comprehensive quota method is adopted, the enterprise may, by transferring the price, the amount of tax paid abroad should be as equal as possible to its tax credit limit in order to fully utilize this tax policy.

\section{The impact of transfer pricing on China}

In recent years, our country has stepped up the control over the transfer pricing of transnational corporations. However, due to the late start, monitoring and lack of laws and regulations, the transfer pricing of transnational enterprises has seriously affected the efficiency of foreign capital utilization in our country and even hindered the economic development of the country. The main impact of the following three aspects:

According to the National Bureau of Statistics of China, in 2014, 55,172 industrial enterprises and units invested by foreign, Hong Kong, Maucao and Taiwan businessmen in China were involved, of which 10,586 were loss units, accounting for $19.19 \%$ of the total, with a total loss of 
155.686 billion yuan, an increase of 7.7\% over 2013. The problem of foreign-invested enterprises' losses is not entirely because of poor management or mismanagement of enterprises. To a large extent, foreign enterprises have adopted a strategy of transferring profits through transfer pricing. The implementation of this strategy has a direct impact on China's tax revenue. Multinational corporations use their internal advantages to maximize the transfer of production factors, reduce costs internally to maximize profits, and use commercial secrecy to create information asymmetries and evade taxation by tax authorities.

Joint ventures are characterized by co-financing, co-operation, sharing of benefits, risk sharing. According to the contract, in the joint venture, China should share profits according to its shareholding proportion. However, transnational corporations use transfer pricing to focus their profits on affiliated enterprises, causing man-made domestic losses in China. However, this kind of loss is in fact "out-of-pocket", which eventually makes China not only unable to share profits, but also needs to bear the loss to a certain extent. When multinationals lose money, they will also reduce their shares in the joint ventures, rendering the Chinese unprofitable and seriously damaging the interests of China.

Multinational corporations through tax evasion, so that the actual tax burden is lower than normal, seriously affecting the fairness of the tax burden, making the normal tax enterprises at a disadvantage. China itself has adopted various preferential tax policies for foreign-invested enterprises and has already caused discrimination against domestic-funded enterprises. Coupled with the tax evasion and tax avoidance by multinational corporations, the unfair competition between domestic and foreign-funded enterprises is exacerbated. This will further lead to the spread of tax evasion and tax avoidance activities in the market and undermine our tax system. In addition, through the transfer pricing, transnational corporations make the prices of products lower than the market prices, which will affect the normal operation of other similar enterprises in our country and disrupt the market environment of fair competition in our country.

\section{Improve China's policy recommendations to deal with the transfer pricing of multinational enterprises}

The "Income Tax Law of the People's Republic of China on Foreign-Funded Enterprises" promulgated in 1991 in our country made the first provision on the transfer pricing of foreign-invested enterprises. The Special Tax Adjustment Implementation Measures (Provisional) promulgated in 2009 has enabled our country to gradually integrate with the international practice in regulating the transfer pricing of transnational corporations, basically in line with the principle of normal transactions. However, due to the complexity of the transfer pricing problem, the relevant laws and regulations in our country are still weak and there is a problem of high cost and low efficiency. Here are the following suggestions: First, to further improve the relevant provisions of the "Enterprise Income Tax Law" and "Tax Collection and Administration Law" on transfer pricing, difficult to avoid problems in practice can learn from the experience of developed countries such as the United States, Britain and other special emphasis The industry can make special provisions in combination with its industry characteristics. The second is to improve the Measures for the Implementation of Special Tax Adjustments and ensure the operability of transfer pricing anti-avoidance management, including expanding the scope of affiliates and narrowing down the criteria for identification and clarification of methods Specific circumstances, improve the contemporaneous data preparation provisions of the specific content; third is to strengthen the transfer pricing management of intangible assets. With the strengthening of pricing management of the transfer of goods and services, the external market prices in this area are more readily available. Many multinationals are turning to tax avoidance through the transfer pricing of intangible assets. Therefore, we should strengthen the pricing of intangible assets, the introduction of the relevant pricing guidelines and standards. Fourth, we need to increase penalties for the transfer pricing. The reason why multinationals have adopted customary transfer pricing in our country is very much related to the current small penalties for transfer pricing. Illegal costs far below profit, from the side to enhance their motivation for tax evasion. Therefore, it is necessary to raise the tax evasion and 
tax avoidance costs of transnational corporations from the legal aspect, strictly enforce the law and give play to the legal deterrent effect so that the cost of illegal activities is much higher than that of illegal profits, so as to fundamentally reduce the transfer pricing behavior. The Law of the People's Republic of China on Tax Collection and Administration shall be amended to clarify the determination of illegal activities and intensify penalties.

While increasing the number of performers in our tax system, we also need to improve the professional qualifications of tax collectors. As the transfer pricing involves tax, accounting, law and other multidisciplinary areas, which requires the relevant tax officers a solid grasp of comprehensive professional knowledge and business skills. Therefore, we should first raise the access threshold of relevant tax officials and conduct rigorous business training after passing the examination. Tax officers who have passed the admission threshold should also regularly conduct training and assessment so as to comprehensively and continuously improve the quality of collection and management personnel. Second, it is necessary to strengthen the quality of the Chinese management personnel in Sino-foreign joint ventures [12]. Chinese business representatives should be familiar with the business of the enterprise, strengthen their management level, eliminate illegal acts such as bribery and bribery, and prevent foreign business representatives from exploiting the export rights of controlled products. Chinese representatives should plot

\section{References}

[1] Zhang Ji. Motives of Transnational Corporations' Transfer Pricing and China's Countermeasures [J]. China Value, 2007 (9):16-19.

[2] Zhang Qiaoqiao. Transferring the internal transfer pricing of multinational corporations on the negative impact of our economy [J]. Economic Times, 2007 (S9): 114-116.

[3] Zhang Ji. Transnational Corporations Transfer Pricing Avoidance Strategy [J]. Statistics and Decision, 2012 (1): 58-61.

[4] Li Yan, Mou Bojiao. Multinational group transfer pricing tax regulation [J]. Finance and Accounting, 2013 (11): 33-35.

[5] Luo Yu. On Trade Protection and Transfer Pricing of Transnational Corporations [J]. Economic Restructuring, 2014(1): 174-178.

[6] Tu Chonghang, Zhang Quanwei. GlaxoSmithKline goldfish exposure [J]. Modern Health b, 2014 (5): 4-5.

[7] He Liantang, Wang Xiaoyue, Sun Yimin. Analysis of transfer pricing case of GSK in the United States [J]. International Taxes, 2007 (10): 61-63.

[8] Huang Min. Multinational Corporations Tax Avoidance and Tax Avoidance - Transfer Pricing Strategic Game Analysis [J]. Times Finance, 2013 (14): 71-72.

[9] Wang Junjie, Yang Jun, He Yurun. Transfer Pricing Issues and China's Regulation of Multinational Corporations [J]. Journal, 2005(4): 87-88.

[10] Ren Zhongtao. On the transfer pricing of multinational corporations [J]. Law and Society, 2014, (22):35.

[11] Xie Hong. Discussion on transfer pricing of multinational corporations in China [J]. Zones Economy, 2013(8): 53-56.

[12] Ge Xuehui. Study on Decision-making and Control Mechanism of Transfer Pricing in International Enterprises [J]. Shandong Journal of Provincial Youth Cadres College, 2009, (4): 115-118. 